\title{
THE ONTOLOGY OF MENTION: CONTEXTS, CONTESTS, AND CONSTRUCTS OF ACADEMIC IDENTITY AMONG UNIVERSITY OF ZAMBIA FACULTY
}

\author{
Ferdinand M. Chipindi ${ }^{1}$ \\ University of Zambia, Zambia \\ Frances Vavrus \\ University of Minnesota, USA
}

\begin{abstract}
This paper examines the implications of the neoliberal reforms of higher education in Zambia for the professional lives faculty at the University of Zambia (UNZA). It draws on interviews with junior faculty-in their positions for less than 10 years-to argue that their conception of academic identity illustrates the problem of the "ontology of mention" (Broudy, 1986; Lungwangwa, 2000), which contends that faculty do not 'exist' in academia unless they publish and are recognized in the publications of other scholars. We also discuss the context under which these academics negotiate their positions in the academy, including material and managerial forces. We argue that junior faculty members in Zambia find themselves torn between the expectation to produce knowledge and the inability of the state to fund their research.
\end{abstract}

Keywords: Accountability, Audit Cultures, Higher Education, Identity, Ontology, Mention

\section{Introduction}

In 1996, the Republic of Zambia enacted a new policy on education known as Educating Our Future (EoF). It went into effect at a time when Zambia was still reeling from two decades of economic decline that followed the immediate post-independence socialist period from 1964- 1974. In 1964, Zambia, formerly known as Northern Rhodesia, gained independence from Great Britain, and, four years later, the first president, Kenneth

${ }^{1}$ Correspondence: University of Zambia, P.O. Box 32379, Lusaka, Zambia; Email: chipio01@umn.edu 
Kaunda, instituted a set of reforms aimed at nationalizing assets, such as the copper mines, and promoting a socialist philosophy that became known as humanism (Kandeke, 1977). However, in the 1970 s the reforms under Kaunda were put to the test when the worldwide drop in copper prices and a sharp increase in the price of oil led to the beginning of two decades of severe economic turmoil in the country. Consistent with neoliberalism (see definition below), the policy transformed higher education in three principal ways: First, the policy promoted deregulation of higher education by reducing state restrictions and control over the higher education sector. Second, EoF laid the foundation for the proliferation of private universities in Zambia. ${ }^{1}$ Finally, EoF fundamentally transformed the funding regime for higher education by declaring that public HEIs needed to increase their sources of revenue and take initiatives to mobilize 'non- government' sources of finance, such as commissioned research, student fees, and consultancy fees.

In this paper, we explore how early-career faculty members at the University of Zambia (UNZA) negotiate academic personhood in an era when state funding for higher education has declined. We examine how these faculty members engage with, appropriate or resist the discourses of accountability, competitiveness, and efficiency in negotiating their professional identities. We focus on comparing two sets of early career faculty members, those from humanities, namely from the Schools of Law, Education, and Humanities and Social Sciences, and those from the sciences, namely, from the Schools of Natural Sciences, Agricultural Sciences, Medicine, Veterinary Medicine, Mines, and Engineering. Our intention in this paper is to examine how these newer faculty members who have been at UNZA for 16 years or less negotiate their scholarly identities in these neoliberal times when the teaching responsibilities have become immense as have the expectations to produce knowledge that is marketable to corporate and other non-governmental entities.

We use Broudy's (1983) concept, the ontology of mention, to highlight the material, monetary and contextual constraints that faculty at UNZA face as they negotiate their professional identities. By ontology of mention, Broudy means that to be is to be mentioned and non-being is brought about by non-mention. He writes, "to be mentioned in the press, on film, on television, in the works of critics creates a being that is shareable by all who read or view" (1983, p. 197). We argue that because of the neoliberal discourses of accountability, competitiveness, and efficiency, early-career faculty members at UNZA face challenges in becoming academically 'alive' through their research and publications. As the responses in the following pages show, some of these faculty feel that being "physiologically alive is insufficient proof of existence" (Broudy, 1983, p. 197); the adage "publish or perish" captures this ontological dilemma and forms an integral part of faculty induction into the academy. More specifically, we look at how the scholarly identities of these faculty are affected by two inter-related discourses: first, the discourse of accountability; and, second, the discourse of efficiency and competitiveness. We show that through these discourses individual identities are constructed for early-career faculty, particularly identities linked to their positioning within the academy.

Our paper is arranged as follows. First, we highlight the key concepts that shape the content and approach in this study. We then discuss the context under which early-career faculty at UNZA negotiate their professional identities. We examine the critical tensions that the faculty navigate as they find themselves torn between the expectation to produce knowledge and the inability of the institution to fund their research and other academic pursuits. More specifically, we look at how the scholarly identities of these faculty are affected by two inter-related discourses: first, the discourse of accountability; and, second, the discourse of efficiency and competitiveness. We show that through these discourses 
individual identities are constructed for early-career faculty, particularly identities linked to their positioning within the academy. Third, we discuss the methods employed in collecting the data for this study. Fourth, we present our findings, based on the conversations we had with ten early-career faculty members at UNZA. We then discuss these findings by showing how the ontology of mention forms a critical part of how these faculty members negotiate academic personhood. We conclude by discussing the significance of our study for comparative and international development.

\section{Theoretical Framework}

Three principal concepts shape the content and approach in this study. The first, and most fundamental, is neoliberalism, which refers to a philosophy marked by a suspicion of the state and so-called 'big government,' which are impediments to both democracy and economic growth (Brown, 2003). Instead, neoliberalism champions the privatization of education and other social services and apportions a greater role for the market in public life, leading to "marketized solutions to educational problems" (Apple, 2001, p. 410). In the Zambian context, neoliberalism is synonymous with 'liberalization,' which means the lessening of government regulations and restrictions in the higher education sector to allow greater participation by private entities in the development of the sector.

Liberalization underpins both EoF and the most recent policy framework for UNZA: The University of Zambia Strategic Plan (UNZASP) 2013-2017. For instance, EoF provides that "within the framework of Zambia's liberalized economy" the "universities and other higher level institutions will be given equal opportunity of access to government consultancies for which they will be expected to compete on an equal footing with other applicants" (MOE, 1996, p. 100; emphasis added). Besides, shortly after EoF went into effect, in anticipation of a competitive higher education climate, UNZA began to undertake 'strategic planning' to increase revenue generation through competitive fees, consultancies, investments, and partnerships. The UNZASP-2013-2017, for example, seeks to reposition the university within the global knowledge economy by offering "industry-relevant products" such as graduates and research outputs (University of Zambia (UNZA), 2012, p. xii). This reflects the competitive spirit with which the institution has begun to approach its functions.

Second, we use the concept of academic capitalism and the related term entrepreneurial university to interpret the political economy of higher education in Zambia. Academic capitalism postulated initially by Slaughter and Leslie (1997), suggests that higher educational institutions have become entrepreneurial in that they must locate sources of funding outside the traditional supplier of finance, the state. For instance, Montero (2010) argues that universities are increasingly concerned with how best to generate the most profit through the sale of research, expertise, and consulting. The concept has additionally led to the production of what Leisyte (2015) has called hybrid academic identities. Due to the allure of commercially funded research, some academics have responded by adopting a hybrid identity that comprises a focal academic self and a secondary commercial persona. By focal academic person, Leisyte means that part of the faculty's identity that is primarily concerned with the core functions of teaching, research and community service. By commercial persona, Leisyte refers to the emerging disposition among contemporary faculty to retain openness towards commercial pursuits either within or outside of the university. In the profit-making scenario of academic capitalism, a faculty member can become merely another actor in the political and economic exchanges between multiple actors within the free 
market. The professional lives of the faculty are renegotiated and reasserted as they encounter new expectations and pressures in their work environments. Academic capitalism has also expanded the roles of faculty to include entrepreneurial functions in their work portfolios. Per Leisyte (2015) "academics are choosing their roles from a more diversified pallet of roles ranging from teaching to academic entrepreneurship” (p. 64).

In the case of Zambian higher education, we observe evidence of academic capitalism in the EoF and UNZASP 2013-2017 and recent policy pronouncements by the Minister of Education. Zambian universities, including but not limited to UNZA, have become increasingly involved in revenue generation since EoF went into effect in the mid-1990s. Both the EoF policy and UNZASP 2013-2017 contend that due to financial limitations of the state, academics ought to teach, conduct research, and engage in consultancies and other forms of academic knowledge production for profit-making purposes. EoF, for instance, provides that the HEIs in Zambia must incorporate an entrepreneurial and profit-motivated orientation in the way they conceptualize their activities, and they must strive to "market themselves more aggressively" (MOE, 1996, p. 105).

The UNZASP 2013-2017 also reveals overt attempts towards the creation of strong links with industry and the corporatization and marketization of the mission of the university. For example, the plan seeks to reposition UNZA for global excellence and a competitive environment and to "develop the capacity to engage in entrepreneurship and business for sustainability and competitiveness in the knowledge economy" (UNZA, 2012, p. 55). Moreover, the Minister of Education in Zambia has recently directed that faculty in Zambia should not only be academicians but also entrepreneurs: "we are looking for men and women who are not only academics but who are also entrepreneurs that can look at the university as an income generating activity" (Funga, 2015, p. 1). Thus, academic capitalism can be observed in the Zambian higher education sector. Questions remain, however, about whether the impacts of academic capitalism such as those reported in the studies of Henkel (2005) and Leisyte (2015) are also occurring within the Zambian academy.

Third, the concept of new managerialism also informs our analysis. Ozga (1998) defines it as the transmission system of business-like models of decision making in higher education. New managerialism focuses on explaining the systems of administration and management that enable the commodification and monetization of knowledge. More specifically, this concept refers to the techniques, values, and practices "derived from the private sector of the economy to the management of organizations concerned with the provision of public services, and to the actual use of those techniques and practices in publicly funded organizations" (Deem, 2001, p. 10). Thus, strategic management principles are transferred from private industry to the public education sector in pursuit of efficiency, effectiveness, and excellence as central tenets of the neoliberal university. In the Zambian context, one sees the influence of new managerialism in the EoF policy. The policy declared that public HEIs, such as UNZA, must develop strategies for revenue generation by becoming entrepreneurial and profit motivated and that these institutions need to harness a greater sense of competitiveness and awareness of the importance of aggressively marketing themselves. Thus, EoF facilitated the transmission of market-based behaviors such as competitiveness, aggressiveness in marketing, and entrepreneurialism to Zambian HEIs as one typically finds in the private sector. New managerialism is also called "audit culture" or "entrepreneurialism" (Shore, 2010; Shore \& Wright, 2000), and we use these terms interchangeably in this paper.

Because of new managerialism, the neoliberal notions of accountability and quality 
have come to define the functions of the academic. Ozga (1998) asserts, for instance, that new managerialism has facilitated the "installation of new forms of steerage and surveillance [in the academy]” (p. 147). By steerage, Ozga means the external controls imposed on the research and teaching agenda of British universities which are manifested through the award of contracts for research together with the short-term and vulnerable employment relations resulting from the selective abolition of tenure. The use of contracts as mechanisms for research steerage and as the basis of short and unprotected employment relations has consequences for the character of research and researchers. Besides, new managerialism has led to a situation where the way the research pursuits of the university are executed is defined by a preoccupation with competitiveness and performativity in the winning of contracts. Faculty are under pressure to produce specific research outputs at the same time as teaching and undertaking managerial and administrative responsibilities.

Ozga also asserts that the entry of managerialism in the research arena transforms the way research problems are handled and how the inquiry is completed and how the effort is managed. Independent assessment of the nature and significance of an issue is replaced by the acceptance of a pre-specified problem by a research team. Ozga contends, additionally, that the identification, pursuit, and management of the research effort have replaced purposeful but wide-ranging intellectual inquiry. Research management has, accordingly, become the paramount activity: "coordination of processes associated with contract winning and maintenance becomes the main concern of the research manager" (p. 147). Instead of objectively and independently ascertaining the merit and significance of a research problem, the new entrepreneurial academic may be compelled under the circumstances to accept prespecified research problems. Also, privileging certain kinds of knowledge and research to the exclusion of not so profitable research pursuits in the humanities and social sciences. Such tendencies, she argues have had adverse consequences for the British academy.

In addition to the EoF policy, new managerial principles are firmly embedded in UNZASP 2013-2017 and provide the framework for university decision-making and restructuring in pursuit of efficiency, effectiveness, and excellence. For instance, in its situational analysis, UNZASP 2013-2017 acknowledges the business opportunities in the country today by pointing out that UNZA is "operating in a liberalized economy in which investment opportunities are numerous" and that it can become self-sustaining through fee payments from students (UNZA, 2012, p. 12). To capture full-fee paying students, UNZA had greatly expanded its enrollments since 2000, when a self-sponsorship scheme was introduced to boost the financial resources of three admitting schools in the University of Zambia, namely, Education, Humanities and Social Sciences, and Natural Sciences (UNZA, 2004). By the 2014 academic year, almost eighty percent of the institution's 21, 000 students were full- fee paying individuals, and the government-sponsored only twenty percent (UNZA, 2014). In contrast, in 1974, 100\% percent of the students at UNZA was sponsored by the government (Chipindi, 2009).

In sum, the three concepts of neoliberalism, academic capitalism, and new managerialism enable us to consider how the professional lives of faculty, particularly junior faculty, at UNZA may be affected by the changes in the political economy of higher education in Zambia. Neoliberalism provides the broader framework through which we explore the economic transformations that have taken place in in the country since the 1990s. Academic capitalism, the commodification of knowledge, and new managerialism allow us to home in on the specific dimensions of neoliberalism that have reshaped higher education in Zambia. Together, these concepts enable us to consider how the professional 
lives of the faculty at UNZA may be affected by the changes in the political economy of higher education in Zambia. Thus, we now turn to examine, how the different dimensions of neoliberalism in higher education discussed above affect one specific group of faculty in Zambia and how local economic and political realities shape their views. In the section that follows we introduce the methods employed in our study.

\section{Methods}

In this study, we used the case study (Yin, 2009) method. This method encompasses diverse methods to capture policies, practices and culturally produced social strata and interactions that are embedded in a specific, bounded research context (Yin, 2009). These methods can range from surveys, focus groups, and ethnographic observations to archival and document analyses and analyses of discourse (Yin, 2009). In our study, we used only one of these methods: semi-structured interviews. These interviews enabled us to explore the discursive practices, as well as the continuously evolving and culturally produced social strata at UNZA, which were at work in the development of professional identity among faculty. Besides, the methods were consistent with the scholarship on qualitative research since they helped us to understand the construction of meaning about identity from our participants' perspectives (Patton, 2015). Dewalt and Dewalt (2002) similarly assert that the art of capturing the specific practices of a social group from multiple angles is a central task before theory building. Our study tried to build knowledge and understanding about how faculty members developed their professional identities in the context of neoliberal reforms of higher education.

The semi-structured Interviews with faculty at UNZA enabled us to gain a better understanding of their feelings, thought patterns, perspectives, and experiences. This helped us to illuminate how these faculty members organized, understood and made meaning of their professional lives in contemporary times, when government support for higher education, in general, had been steadily depleted. The interviews helped us to understand better how faculty members developed their professional identities about shifts in the ideological landscape and the discourses that were prevailing at each epoch during UNZA's history.

The semi-structured interviews had the advantage of providing "access to the cultural categories and assumptions according to which one culture construes the world" (Meisenbach, 2004, p. 73). Seidman (2006) describes an interview as an inter-subjective exchange between an interviewer and an interviewee, at the root of which lies "an interest in understanding the lived experiences of other people and the meaning they make of that experience... an interest in other individuals' stories because they are of worth" (p. 10). Since the aim of our study was to explore how different generations of faculty members made sense of their professional lives, it was necessary for us to obtain their perspectives on identity developed at various stages in the history of the institution.

We interviewed a total of 10 participants whom we purposely selected before the start of fieldwork in June of 2016 . We interviewed five faculty members from the humanities and five from the sciences. The ten faculty members had served from four to 16 years. Of those interviewed, eight were female, while two were male. Five of the participants had a master's degree, while five had completed their Ph.D. Eight of them had obtained their highest qualifications from within Africa; one from Australia; another from Belgium.

We purposively selected one early-career faculty member from each of the nine Schools at UNZA, and then we randomly picked the tenth participant through a lottery 
system. For this study, we grouped the nine Schools at UNZA into two broad streams. Stream A Included the humanities because the schools in this stream had a robust humanistic orientation. The humanities, as defined in this study, consists of three closely aligned schools: The School of Education, the School of Law and the School of Humanities and Social Sciences. Stream B focuses on the sciences. It consists of six schools, namely, the School of Veterinary Medicine, the School of Agricultural Sciences, the School of Mines, the School of Engineering, the School of Natural Sciences and the School of Medicine. The schools in this stream have an extreme scientific focus and correspond to what is often called Science, Technology, and Mathematics (STEM).

\section{The Ontology of Mention}

Our conversations with the faculty members revealed a divergence of views on the fundraiser role that is cast upon them by the university administration. Those faculty who accepted an added fundraiser identity asserted that any fundraiser roles should be adequately rewarded in the promotion system. This has implications for the ontology of mention because faculty who supported the fundraiser role tended to do so on account that it will lead to their becoming alive academically when the promotion committee acknowledges their hard work and rewards them with a promotion. Below, we provide two examples of how some faculty members envisioned the reward system for fundraising.

Our interview with Vasliona, an early-career academic who recently obtained her doctorate in education from a local institution and who is from the humanities, provided substantial evidence of how faculty members used the ontology of mention to articulate their academic identity. She described a project which she and two other senior colleagues had applied for and obtained funding. She considered it a significant achievement for her name to be associated with a project that brought vast amounts of money into the institution. She stated the following when we asked her what it meant to have secured funding for UNZA in an open competitive process:

I do not know what I can say. Of course, it is nice to have your research published and to be visible to other scholars in your field but to have my name associated with big money coming into UNZA is a tremendous achievement which will change how the leadership in the university looks at me. They will probably say 'oh that is Vasliona and she is one of those that brought so much money into the university.' This way, my name will be part of the history books, as one of those successful academics that brought monetary value. It is hard to erase that kind of accomplishment, just like you cannot delete the publication record of someone. (Interviews, 0001, December 2016).

Ndyokaak, from the humanities, provides a second example of how early-career academics view fundraising. She asserted that bringing money into the university represented, for her, an improvement in her standing in the eyes of her peers and her superiors. She said she tried to make sure that she got involved in big projects so that when her name is associated with a significant project that brought money into UNZA, it helped to make her visible even in the meetings:

In my field, I don't know if it is just in the humanities generally, I don't know if it is only at UNZA, the general UNZA thing and you know how it is to move from one level to another, Lecturer III to II, where you're expected to 
demonstrate accomplishments in specific areas, so research apparently is a big one and securing funding for projects which is another huge one. So, if you can say look I did this consultancy, and this is how much I money brought in to the University then that goes a long way. But not only that you get involved in this consultancy and it is shared among peers, so it kind of like puts you in a position of you know what maybe I should use the word respect or recognition or acknowledgment so that if you put up your hand to say something in a group people will not look over you and go for the person next to you. So, for me, I think as a person that means a lot to me. (Interviews, 0002, January 2017)

Here again, the ontology of mention is illustrated. Ndyokaak believed that her respect among peers was elevated when her name was associated with some prominent consultancy that brought money for the institution. When faculty members attend a meeting, people frequently indicate their willingness to speak by raising their hands so that the chair of the meeting can point at them and give them a turn to contribute.

At times the chair must choose from several options hands, and some faculty members end up not getting a turn to participate. However, what Ndyokaak was saying was that raising money through consultancy increased her visibility in the meetings, and with that, her chances of being mentioned were also raised. She could attend the meeting as an active, recognized participant who could be mentioned by name, and that meant a lot to her. She elaborated that the mention elicited by being associated with a significant project was like being visible only because one was walking alongside a renowned professor:

The University atmosphere can reduce somebody to something minimal. They can reduce you to something tiny. I think it is not here. I used to see it even at my University when I am walking with my supervisor because he was a big person, he was a Professor, and he is a leading scholar in the area, and he was Dean at the Faculty where I was. So, it was a case of where people would not even acknowledge me when I am on my own, but if I am walking with him, people greet me by name. Suddenly you are being invited to say 'could you can we want you to come and give this talk...So, there's this ranking system people must earn stripes and when you reach a certain level even the way you talk, what you can say you will be given a platform to express yourself, people even listening to you. I mean if you do not care, it is okay. You can afford to sit in a corner within the University, and nobody will ever recognize you. However, if you want that recognition then you must go out there you must keep yourself out, and people must know who you are. (Interviews, 0002, January 2017)

Ndyokaak's sentiments further illustrate how mention can be gained when one's name begins to be associated with projects. One can notice that walking alone, without any merit to her name, Ndyokaak feels that she is not alive, but the moment her name turns up alongside a recognizable figure, such as a well-known professor, doors begin to open for her to be invited to various functions within the academy. The metaphor of earning stripes can be related to military life, where the number of lines a marine has indicated their seniority. In the academy, these stripes likely refer to being mentioned, to become academically alive by whatever means possible. 
Omutima, another early-career faculty member who hailed from the sciences and who obtained her doctorate less than three years before the interview, told us that the performance appraisal system (PAS), which UNZA has been trying to implement for some time, was an excellent system for increasing her chances of being mentioned. The PAS is a system of evaluating and measuring the performance of the faculty at UNZA, as well as the other support staff. It works by subjecting each faculty member to a checklist that quantifies and measures how they have performed in each academic year. All aspects of academic life are broken down into bullet points that can be measured. In support of the PAS, Omutima stated the following in response to our question about PAS, which shows that her views are aligned with the administration's notion of excellence:

My take on this appraisal system is it is a right way of doing things, but like I said there's need for proper administration of the same system. If you come to me and ask me to account for my time, I should be able to show you by the number of students I am teaching; the number of hours I stand in front of those students and so forth. You get a script that has been marked, it looks like it has not been marked, but marks are there [implying that some faculty members do not score the student assignments but just put marks]. So, for me being accountable regarding hours to teach because teaching is mandatory. Every lecturer is supposed to teach. That is the core business of the University and so that one must be done. (Interviews 0003, December 2016).

In her responses, Omutima conveyed two critical points. First, she justified PAS because it could help to improve the operations of UNZA by creating space and time for her to pursue her publication agenda. She blamed the nature of some of the other faculty members, whom she believed were at times not committed to their work and thought that only some form of appraisal might help to keep them motivated. Second, Omutima believed that quantification of an academic's work life, through PAS, would help catch the faculty members that were not doing their jobs efficiently, and this would in turn help to apportion teaching responsibilities more evenly so that faculty could do research, publish, and become alive academically.

Napoleon, an early-career scholar from the humanities, similarly agreed with the need for PAS because of the weak working culture of some individuals within the Zambian academy. He, however, contended that caution needed to be exercised in implementing the system. Napoleon asserted that there was a need to "adapt" the PAS to suit the scenario in the academy. By this, he meant that since the idea of appraisal emanated from the business world, it might not be adapted to the university, where faculty members work late into the night, long after the working hours. He, therefore, urged that the university administration need to think the system through critically. He stated the following when we prompted him to say a little bit more:

That is primarily human nature because may be in the weakness of the system somebody will decide to say even if I do this; nothing will happen to me which, unfortunately, is something we cannot promote. So, some measures must be put in place, but they should be measures that whoever intends to implement should sit and critically look at it. It should not just be one thing you copy from here and paste as is because it is bound to fail because we are looking at the nature of the work that we do. I am not against having a Lecturer evaluated 
by students regarding lecturing. That could be one of the ways to assess the Lecturer. So, the monitoring, I know UNZA is about to implement that, the control is necessary but I think we need to have one that is meant for this scenario. It is intended for this scenario. Otherwise, the check in, check out with a finger, fingerprints. (Interviews, 0004, December 2016)

Hillary, another early-career academic from the sciences, indicated that the responsibility to participate in raising funds for the institution was, for her, virtually "inescapable." She told us that throughout her time at UNZA, she had tailored her academic identity towards financially-viable research pursuits. Her lamentations below, highlight some of the challenges that arise from her substantial teaching responsibilities:

Maybe that's one way of the university trying to cushion the funding so the effect that [expanded enrollment of students] has on a young lecturer like me is the fact that I have close to 200 students in this course that I teach and you are telling me that the specimens for example, for dissection, are very limited so out of a student population of let's say 170, and you only have ten [brains][reagents] available for them to dissect and study so then some particular years we've had to go without students even being able to examine a brain at 4th year, which is very sad and uncalled for. However, because the numbers [of students] are being dictated by some higher policies you know. It has been very frustrating I think partly because of the large numbers like I said which happen to be some higher policy, some higher call to say can you increase the enrollment of medical students so we can have more graduates in this profession. However, on the ground, they are not working on the capacity building from the faculty aspect. (Interviews, 0005, January 2017)

This excerpt amply illustrates Hilary's frustration with higher powers, namely the Senate or Council. She felt she had no authority to determine how many students she can take on because such a decision is not hers to make. These added responsibilities did not help Hilary's identity as a researcher.

Munkondia, also from the sciences echoed Hilary's frustrations. Munkondia told us that owing to the expansion in student enrolments in her School, and it was hard for her to find time to research, get published and get recognition as a scholar when all her time is consumed attending to students as if teaching is the only calling she had in the job:

The other negative impact has been the fact that because of the burden of teaching the substantial number of students it gives you very little time for research. You find the only time that you can do significant research is because you have enrolled in a Ph.D. program. So now you are sort of... They leave you with very little time. So, that has been the effect. That has been the adverse effect anyway. (Interviews, O0010, January 2017)

Munkondia's reflections illustrate the perceived powerlessness of some faculty in the neoliberal university, as well as their deep frustrations with the rapidly deteriorating working conditions. Importantly, these conditions had not led to a relaxation of the promotion criteria, as these remained static, with every academic expected to demonstrate outstanding contributions in research, teaching and community service to earn promotion from one rank 
to the next. Thus, the somewhat reluctant appropriation of this added fundraiser-academic identity has been accompanied by shadowing of some or all the other dimensions of identity. Munkondia believed that because the institution expected her to generate revenue by teaching an expanded student body, it somehow affected her ability to become alive more fully.

Similarly, we solicited Cyprian's opinion on whether the job of a faculty member should include the generation of revenue for the institution. Cyprian had just completed his Ph.D. studies and was from the humanities. He responded that raising money for the institution was "definitely" important:

Of course, of course, I think it is essential that you see the client for any University is the student, of course, that is the priority because we are here to teach that client. So, when we are teaching, we are bringing in money for the University to sustain the institution and sustain ourselves as employees of the institution. We have two types of research. There's research for just knowledge purpose; you research to generate knowledge which will benefit people and such investigations usually may not have monetary gain. However, there's also consultancy which will bring in money into the institution. That is very critical. In other universities, abroad and even within Zambia, you are promoted to the rank of Professor, Senior Professor, full Professor and so on whatever they may call you, based on the money that you are bringing to the institution. (Interviews, O006, November 2016)

Cyprian went on to say that research that brings in money should be prioritized over research that does not. He said: "Given the financial constraints that the University is faced with, I think of course research which is bringing in money to the institution will be given priority because it is that money which will support research that may not generate any income" (Interviews, 0022, November 2016). Whether Cyprian's claim that the promotion of faculty is based on the ability to bring money does not apply to the Zambian academy is debatable. The senior faculty members who sit on the promotion committee of UNZA told us that revenue generation has not yet been incorporated into the promotion criteria, adding that promotion was based more on publications, and not on the amount of money brought into the institution.

However, other respondents, while not roundly objecting to the fundraiser-academic roles, said they would be much happier to fulfill this role if it were incentivized by, for instance, being incorporated into the promotion criteria. Dudu, an early-career faculty member from the sciences, asserted that she welcomed the added task of fundraising given the unsound financial health of the institution, noting, however, that it should be enriched by being included in the performance indicators for promotion or renewal of contract:

It is essential for someone to raise funds for his or her research, for the institution, I think that is very important. However, having it put in as a specific, maybe in the job description, would make it more attractive to me. I can be encouraged to take part in it if it is recognized as an indicator of my performance, as an academic, possibly for promotion or something to say 'this one brought funds so we can promote this person because I think the playing field is not right. (Interviews, 0007, January 2017) 
This quotation suggests that Dudu was not opposed to raising funds if it could help her to become academically alive. She wanted this responsibility inserted into the performance appraisal so that somehow she can earn points that count towards her promotion whenever she generates funds for the institution. By referring to the playing field as not being level, Dudu implied that revenue-generation would contribute to her becoming academically alive.

Chameya, a lecturer from the humanities, echoed this view and added that it should not be mandatory for academics to double as fundraisers for the institution unless the university leadership builds adequate reward systems for the recognition of this role into promotion criteria:

I think it should not be necessary. I think it should not be mandatory. Moreover, unless the University also may be factors that into how people get to advance because now the current set up is on teaching and research but the fundraising issue. I mean we need to do something if it brings in money for the university then that is great, but I do not know if we should make it mandatory. Because lecturers and researchers are it all of us, who have got entrepreneurial thinking at the end of the day? (Interviews, 0008, January 2017)

On the other hand, Malakai, who hailed from the sciences, argued that fundraising should somehow be equated to publications. Malakai said the fundraiser function should be adequately rewarded in the promotion system so that the fundraising activities of the faculty members are appropriately cited and rewarded:

Now the institution needs to run, and it needs to run with some funding. Now if I am going to be made the primary source of funding, then I have got a bit of a challenge. It means now I must get a chunk of my time and put it into consultancy so that I can generate money for the institution. I have got no problem with contributing, but my contributions must be adequately mentioned and rewarded by the university leadership, especially when I apply for promotion. (Interviews, 0009, December 2016)

These reflections of the faculty to the added responsibility of fundraising for the university demonstrate that in the Zambian academy, diverse scholarly identities are formed as individuals with different locations within it, and various personal preferences interact with the neoliberal environment in which they work. Amidst great material, financial and logistical constraints, the faculty at UNZA recognize and act upon or confront their limitations. These faculty members were willing to assume a fundraiser identity because they believed that it helped them to get the chance to be mentioned.

\section{Significance and Conclusion}

This study has explored the experiences of early-career faculty about how their professional lives as academics undergo re-constitution in a corporatized campus milieu, with a view of adding these African faculty perspectives and experiences into the ongoing conversation of faculty development globally. The support for a fundraising role for academics was invariably linked to the opportunities for mention that were available for either set of the faculty. We hope that the voices and experiences of our participants can elicit more discussion and offer recommendations for staff development at the University 
of Zambia and other public universities in the country and Sub-Saharan Africa. An understanding of how early-career faculty are negotiating their professional identities in a liberalized market economy might yield critical insights into the future configuration of the higher education enterprise and the knowledge production functions of higher education institutions.

Exploring how the neoliberal forces of privatization, liberalization, and corporatization are perceived, appropriated, adapted, and contextualized within the Zambian academy, as part of the neoliberal reform of higher education, is significant because the success of such reforms in one context (global North) does not guarantee that they will work as intended in another region. This is particularly important because national contexts differ regarding the political history of the country, the gravity of economic problems previously or presently faced, and the extent to which the country embraces the notion of a free market economy as prescribed by the IMF and the World Bank. In this regard, examining perceptions, voices, and experiences of faculty at UNZA not only gives knowledge on regional and institutional approaches to neoliberal reform of higher education but also offers insights into the destructive and desirable potential of these neoliberal forces in improving or ruining higher education.

This study builds on scholarship on how policy and ideas travel and how they get localized and gain different forms and meanings (Bartlett \& Vavrus, 2014). Ideas of neoliberal reform typically originate from Western countries (Altbach, 2004). The rationales and values of entrepreneurial forms of higher education emanate not only from the epistemological and ontological standpoints of the seminal western thinkers but also their cultural and axiological standpoints (Crotty, 1998; Leisyte, 2015; Ramirez, 2006). Therefore, it is essential to explore how local actors- early-career faculty at UNZA in this case- appropriate neoliberal forces and how they are reconfigured to local realities, meanings, and contexts (Dean, 2012), while also highlighting the ways that such localizations embody universal principles in global contexts. Similarly, the study can provide room to compare theoretical assertions of the impact of neoliberalism on higher education in general to actual processes, perceptions, and experiences of faculty whose identities and the ongoing reconfiguration of higher education has altered roles in Zambia. This can illuminate the intricacies of neoliberal reform of higher education in the global South and provide room for future comparative studies on the corporatization and commodification of knowledge.

The significance of this study for the field of Comparative and International Development Education (CIDE) lies in the charting of new ground in the study of the impact of neoliberalism on the professional identities of faculty in a geographical locale that is understudied. Despite the steadily growing literature on the upheavals occasioned on higher education with the attendant transformation of the identities of individuals who inhabit this space, most of the studies have been conducted in Europe, America, and the Asian Pacific region. In this study, however, we looked at the impact of neoliberalism in southern Africa, an area where higher education is undergoing neoliberal reforms but has not been studied extensively.

\section{References}

Agger, B. (1991). Critical theory, poststructuralism, postmodernism: their sociological relevance. Annual Review of Sociology, 17(1), 105-131. http://doi.org/10.1146/annurev.soc.17.1.105

Altbach, P. (2004). Globalization and the university: myths and realities in an unequal world. Tertiary Education and Management, 10(1), 3-25. 
Apple, M. W. (2001). Comparing neoliberal projects and inequality in education. Comparative Education 37(4), 409-423.

Bartlett, L., \& Vavrus, F. (2009). Introduction: Knowing, comparatively. In F. Vavrus \& L. Bartlett (Eds.), Critical approaches to comparative education: Vertical case studies from Africa, Europe, the Middle East, and the Americas (pp. 1-20). New York: Palgrave Macmillan.

Bartlett, L. \& Vavrus, F. (2017). Rethinking case study research: A comparative approach. New York: Routledge.

Bartlett, L., \& Vavrus, F. (2016). A vertical case study of global policy-making: Early grade literacy in Zambia. In K. Mundy, A. Green, B. Lingard \& A. Verger (Eds.), The handbook of global education policy (pp. 554-572). Thousand Oaks, CA: John Wiley \& Sons.

Bartlett, L., \& Vavrus, F. (2014). Transversing the vertical case study: methodological approaches to studies of educational policy-as-practice. Anthropology and Education Quarterly, 45(2), 131-147.

Broudy, H. S. (1983). The ontology of mention. Educational Theory, 33(3\&4), 197-198. Brown, W. (2003). Neo-liberalism and the end of liberal democracy. Theory \& Event 7(1). doi: $10.1353 /$ tae.2003.0020

Chipindi, F. M. (2009). The quality-quantity trade-off: implications of expanded enrolments at two of Zambia's public universities (Unpublished master's dissertation). University of Zambia (UNZA), Zambia.

Cooley, A. (2013). Qualitative research in education: the origins, debates, and politics of creating knowledge. Educational Studies, 49(3), 247-262. http://doi.org/10.1080/00131946.2013.783834

Crotty, M. (1998). The Foundations of Social Research: Meanings and perspectives in the research process. Sydney: Allen and Unwin.

Dean, M. (2012). Rethinking neoliberalism. Journal of Sociology, 50(2), 150-163. http://doi.org/10.1177/1440783312442256

Deem, R. (2001). Globalization, new managerialism, academic capitalism and entrepreneurialism in universities: Is the local dimension still important? Comparative Education 37(1), 7-20.

Funga, M. (2015, June 2). UNZA needs entrepreneurial managers - Kaingu. The Post. Retrieved from http://www.postzambia.com/news.php?id=8972

Harvey, D. (2005). A Brief history of neoliberalism [Kindle Edition]. Oxford: Oxford University Press.

Henkel, M. (2005). Academic identity and autonomy in a changing policy environment. Higher Education, 49(1-2), 155-176. http://doi.org/10.1007/s 10734-004-2919-1

Johnson, A. T., \& Hirt, J. B. (2010). Reshaping academic capitalism to meet development priorities: the case of public universities in Kenya. Higher Education, 61(4), 483-499.

Kandeke, T.(1977). Fundamentals of Zambian humanism. Lusaka: NECZAM

Klein, N. (2007). Shock doctrine: The rise of disaster capitalism. New York: Picador.

Leisyte, L. (2015). Changing academic identities in the context of the managerial university: Bridging the duality between professions and organizations. In W. Cummings \& C. Teichler (Eds.), The Relevance of academic work in comparative Perspective (pp. 59-73). Zurich: Springer International. http://doi.org/10.1007/978-3-319-11767-6_4

Levidow, L. (2007). Marketizing higher education: neoliberal strategies and counterstrategies. In E.W. Ross \& R. Gibson(Eds.), Neoliberalism, highereducation andreform (pp. 237-255). New Jersey: Hampton Press.

Lungwangwa, G. (2000). Adherence to excellence: The challenge of the ontology of mention for a university in a developing country. In H.J. M'sango, E.C. Mumba \& A.L. Sikwibele (Eds.), Selected topics in philosophy and education (pp. 164-171). Lusaka: 
University of Zambia Press.

Mamdani, M. (2007). Scholars in the marketplace: The dilemmas of neo-liberal reform at Makerere university, 1989-2005. Dakar: Council for the Development of Social Science Research in Africa.

Meisenbach, R. J. (2004). Framing fundraising: a poststructuralist analysis of education fundraisers' work and identity (Unpublished doctoral dissertation). West Lafayette: Purdue University.

Ministry of Education (MoE). (1996). Educating our future: National policy on education. Lusaka: Government Printers.

Montero, H. V. (2010). The construction of professional identity and pathways of participation of fulltime faculty members in university restructuring in Mexico (Unpublished doctoral dissertation). University of California, Riverside.

Moyo, D. (2009). Dead aid: Why aid is notworking and how there is a betterway for Africa. New York: Farrar, Straus and Giroux.

Ozga, K. (1998). The entrepreneurial researcher: re-formations of identity in the research marketplace. International Studies in Sociology of Education, 8(2), 143-153. http://doi.org/10.1080/0962021980020024

Patton, M.Q.(2015). Qualitative research and evaluation methods: Integrating theoryand practice (4th ed.). Thousand Oaks, CA: SAGE Publications, Inc.

Peshkin, A. (1993). The goodness of qualitative research. Educational Researcher, 22(2), $28-38$.

Ramirez, F. (2006). Growing commonalities and persistent differences in higher education: Universities between global models and national legacies. In H.D. Meyer \& B. Rowan (Eds.), The New Institutionalism in Education (pp. 131-141). Albany: State University of New York Press.

Slaughter, S., \& Leslie, L. L. (1997). Academic capitalism: Politics, policies, and the entrepreneurial university. Baltimore, MD: John Hopkins University Press.

Strauss, A., \& Corbin, J. (2015). Basics of qualitative research: Techniques and procedures for developing grounded theory. Thousand Oaks, CA: SAGE Publications, Inc.

Talmy, S. (2011). The interview as collaborative achievement: interaction, identity, and ideology in a speech event. Applied Linguistics, 32(1), 25-42.

Torres, C. A. (2009). Education and neoliberal globalization. New York: Routledge.

Torres, C. A., \& Schugurensky, D. (2002). The political economy of higher education in the era of neoliberal globalization: Latin America in comparative perspective. Higher Education 43(4), 429-455.

Vavrus, F., \& Bartlett, L. (2006). Comparatively knowing: making a case for the vertical case study. Current Issues in Comparative Education, Teachers College, Columbia University, 8(2), 95101.

\section{About the Authors}

Ferdinand Mwaka Chipindi is currently a lecturer at the University of Zambia, in the Department of Educational Administration and Policy Studies. He recently completed his doctoral studies in Comparative and International Development Education (CIDE) from the University of Minnesota, Twin Cities. His doctoral research titled "Negotiating professional identities in a liberalized Sub-Saharan African economy" investigated the discourses that have come together at different moments in the past 53 years to produce different types of identity among faculty members within the Zambian academy. By identity, Ferdinand means a concept that encompasses an eternal cycle of personas and positions that are articulated, adapted and discarded through the interactions of the faculty with the political, economic and social environment. The implications of Shifts in the ideological landscape of Zambia, since 
the advent of neoliberalism in 1991, are investigated. The study invokes a poststructuralist lens to argue that in the Zambian academy, the concepts of self, work, and environment are continuously co-created through social interactions. Ferdinand also holds a Master of Education and a Bachelor of Arts with Education, both from the University of Zambia. Ferdinand's research interests include Higher Education, Political Economy, Comparative Education, Educational Policy and Social Change.

Frances Vavrus is Professor of Comparative and International Development Education at the University of Minnesota. She is also affiliated with the university's Human Rights Program; Gender, Women, and Sexuality Studies; and the Interdisciplinary Center for the Study of Global Change. Also, Dr. Vavrus is the International Labor Organization's representative for North America on the Joint ILO/UNESCO Committee of Experts on the Application of the Recommendations Concerning Teaching Personnel, a United Nations body that reviews teachers' rights violations and makes recommendations on how to improve the teaching profession globally. Dr. Vavrus has examined the legacies of colonialism and regional inequalities in education, health, and foreign aid in sub-Saharan Africa with a focus on Tanzania. She has served as a high school teacher and university lecturer in the Kilimanjaro Region and has been engaged in a long-term community ethnography on Mount Kilimanjaro exploring how secondary schooling affects the lives of youth. She is the author/coauthor of four books and has published widely in such venues as AIDS Care, Anthropology and Education Quarterly, Comparative Education Review, Harvard Educational Review, and the Journal of African American History. 